University of Nebraska - Lincoln

DigitalCommons@University of Nebraska - Lincoln

Management Department Faculty Publications

Management Department

10-2005

\title{
Nurturing the spirit at work: Impact on work unit performance
}

\author{
Dennis Duchon \\ University of Texas at San Antonio, dduchon2@unl.edu \\ Donde Ashmos Plowman \\ University of Nebraska-Lincoln, dplowman2@unl.edu
}

Follow this and additional works at: https://digitalcommons.unl.edu/managementfacpub

Part of the Management Sciences and Quantitative Methods Commons

Duchon, Dennis and Plowman, Donde Ashmos, "Nurturing the spirit at work: Impact on work unit performance" (2005). Management Department Faculty Publications. 65.

https://digitalcommons.unl.edu/managementfacpub/65

This Article is brought to you for free and open access by the Management Department at DigitalCommons@University of Nebraska - Lincoln. It has been accepted for inclusion in Management Department Faculty Publications by an authorized administrator of DigitalCommons@University of Nebraska - Lincoln. 
Published in The Leadership Quarterly 16:5 (October 2005), pp. 807-833; doi:10.1016/j.leaqua.2005.07.008

Copyright (C) 2005 Elsevier Inc. Used by permission

Published online September 8, 2005.

\title{
Nurturing the spirit at work: Impact on work unit performance
}

\author{
Dennis Duchon and Donde Ashmos Plowman \\ Department of Management, University of Texas at San Antonio \\ Corresponding author - D. Duchon, $\underline{\text { dduchon@utsa.edu }}$
}

\begin{abstract}
Workplace spirituality is defined as a workplace that recognizes that employees have an inner life that nourishes and is nourished by meaningful work that takes place in the context of community. This definition, based on three fundamental spiritual needs, has implications for how leaders can enhance work unit performance by nurturing the spirit at work. In an exploratory study of six work units in a large hospital system we used an instrument that measures workplace spirituality. The results led to propositions concerning the effect of work unit spirituality on work unit performance and the relationship between work unit spirituality and leadership. Among medical units within the same hospital system, work unit spirituality is greater in some than in others; work unit performance is associated with work unit spirituality; and work unit leaders likely have an impact on the degree to which work units acknowledge and encourage issues of the spirit.
\end{abstract}

Keywords: workplace spirituality, spirituality and leadership, unit performance

\section{Introduction}

In the past few years there has been a growing interest in workplace spirituality, in part due to what some are calling "a spiritual awakening in the American workplace" (Garcia-Zamor, 2003, p 355). Since the late 1990s publications such as Wall Street Journal, Business Week, Fortune and others have reported a growing desire among employees for meaning and purpose at work, for a spiritual dimension to organizational life. Anecdotal evidence suggests that work- 
places differ in terms of their commitment to building and nurturing people's spirits (Kolodinsky et al., 2003; Pfeffer, 2003) yet little is known, empirically, to support these claims. Further, the interest in workplace spirituality has led to the assertion that workplaces that are "spiritually healthy" (White, 2003), most likely perform better (Elm, 2003; Garcia-Zamor, 2003) and are, in part, a function of the attitudes, practices and behaviors of workplace leaders (Fry, 2003; Pfeffer, 2003; Strack et al., 2002).

In an exploratory study of six work units within one large healthcare system we examine workplace differences in terms of their openness to spirituality, and whether these differences are associated with differences in work unit performance. Finally, we consider the degree to which the attitudes towards workplace spirituality of unit leaders reflect the attitudes of their subordinates, and develop implications about the role of leaders in nurturing the spirit at work. In spite of the growing interest among practitioners in matters of the spirit or heart at work, organizational scientists have been slow to address the topic. For example, to date, no articles on the topic of spirituality and organizations have appeared in the four most prestigious organizationally-oriented academic journals-Academy of Management Journal, Academy of Management Review, Administrative Science Quarterly, or Strategic Management Journal. Although in 2000, the Journal of Management Inquiry published a special issue that included articles on Spirituality, and book reviews and a review article appeared in 2001 and 2003 respective issues of The Leadership Quarterly.

In spite of such paucity, Pfeffer (2003) points out that given how much time people spend at work and how work is partly responsible for people's social identity it is time to examine the differences between management practices that nurture people's spirits and those that harm the spirit. Thus, leaders who practice spirit building vs. spirit destruction can have a significant impact on organizational life and ultimately organizational success.

Although largely ignored, workplace spirituality has started to emerge as a domain of interest to a small circle of organizational scientists. Mitroff, Mason \& Pearson (1994), for example, envisioned radically different organizations of the future that would house, among other things, world service/spiritual centers for connecting the organization's purposes to solving the world's problems. Their notion of spirituality was not explicit and seemed to focus more on the need for corporate social responsibility than on people's needs for meaning in their lives. But theirs was an effort to go beyond the boundaries of conventional views of organizations. Conger (1994) also stepped outside the conventional boundaries when he coupled ideas from organizational management such as leadership, motivation, and structure, with those such as meaning, community, and morality, from several major spiritual traditions in his book Spirit at Work. There has been little follow-up, however, to Conger's work, at least in management journals.

One notable exception is Mirvis (1997) who considers the implications of "soul work" for organizations, primarily as it relates to "community building." A second notable exception was a special issue of Journal of Change Management (1999) devoted to examining the presence of spirituality in both individuals and organizations. Another exception is the 2000 issue of Journal of Management Inquiry which devoted some space to issues of spirit at work. For example, in that issue, Delbecq (2000) provides a description of an MBA course he teaches entitled "Spirituality for Business Leadership," and Ashmos \& Duchon (2000) report an empirical effort to develop a measure of spirituality at work.

It is also important to note that the scholarly work addressing spirituality in the workplace is only now beginning to move from a conceptual phase to a theory building-empirical testing phase. For example, while Fry and his colleagues (cf. Fry et al., 2005; Malone \& Fry, 2003) 
have recently begun to present empirical evidence in support of his theory of spiritual leadership (Fry, 2003), such empirical work has been the exception, not the rule in the area of spirituality scholarship. Even Mitroff \& Denton (1999, p. 83), who conducted one of the few empirical studies of workplace spirituality note, "even the few studies of spirituality in the workplace by respected academics are written more from the heart than from the stance of critical inquiry." More typical is Handbook of Workplace Spirituality and Organizational Performance of Giacalone \& Jurkiewicz (2003) which offers a collection of articles devoted to the concept of workplace spirituality, none of which report empirical work. The authors even raise, specifically, the very question that is addressed in this article: "Is spirituality significantly related to various aspects of organizational behavior and performance, and if so, how?" (p. 21).

In developing a context for this exploratory study we begin by grounding the notion of workplace spirituality in organization theory constructs. This shows that workplace spirituality has its roots in a number of familiar organizational behavior and organization theory constructs. We then explore, in a small sample study of six medical care units within a large hospital system, the relationship of work unit spirituality and work unit performance. We present evidence that those who score high on a measure of workplace spirituality, which we refer to as "spirit friendly" work units out perform those that are less spirit-friendly. Finally, we offer a set of propositions for further examination of the relationship of work unit spirituality, leadership, and work unit performance.

\section{Workplace spirituality}

Workplace spirituality is a new topic to organizational literature and is a topic with limited theoretical development (Dehler \& Welsh, 2003; Fry, 2003; Giacalone \& Jurkiewicz, 2003). The history of "work" has been well documented by others (Dehler \& Welsh, 2003; Pine \& Gilmore, 1998) and is beyond the scope of this paper. However, we begin with a definition of workplace spirituality. A workplace can be considered to be spiritual (or spirit friendly) when it recognizes that employees have an inner life that nourishes and is nourished by meaningful work that takes place in the context of community (Ashmos \& Duchon, 2000). A number of the contributing authors to the recent Handbook of Workplace Spirituality and Organizational Performance (Giacalone \& Jurkiewicz, 2003) offer slightly different definitions but many of them draw on the components of the definition developed by Ashmos \& Duchon (2000): inner life, meaningful work, and community. Our confidence in this definition is also increased by the notion of Fry (2003) that spiritual leadership is partly a function of "calling" which is similar to our notion of meaning, and "membership" which is similar to our notion of community.

While the organizational behavior literature has examined the emotional (Brief, 2001; Brief \& Weiss, 2002; Morris \& Feldman, 1996) and cognitive side of organizational life (cf., Fishbein \& Ajzen, 1975; Vroom, 1964), little work has examined the spiritual side of organizational life. The lack of attention by organizational scientists to spirituality can be explained partly by the nature of academic inquiry, that focuses on more readily observed and measured behaviors and their presumed covariates (i.e., attitudes) than something elusive and idiosyncratic (spirit or spirituality). The lack of attention can also be explained by a generally secular approach to the study of organizational life. Religion gets scant attention in the literature, and so, by extension, spirituality is likewise ignored. It is important to note that religion (an organized belief system) and spirituality (an inner longing for meaning and community) are not the same thing. Mitroff \& Denton (1999) reported that people in the workplace can distinguish between 
religion and spirituality, and believe that spirituality is an appropriate topic for discussion in the workplace while religion is not. We focus here on spirituality, not religion, much in the same way as Bolman \& Deal (1995).

\subsection{Workplace spirituality-A definition}

One of the difficulties in addressing the topic of spirituality and organizational life is in articulating a suitable working definition of workplace spirituality (Giacalone \& Jurkiewicz, 2003). Most definitions of workplace spirituality include the notions of meaning, purpose and being connected to others (Ashmos \& Duchon, 2000; Conger, 1994; Giacalone \& Jurkiewicz, 2003; Mirvis, 1997; Vaill, 1998, 2000). Vaill (2000), for example, views spirituality as having to do with human kind's search for meaning, and argues that the search for meaning for many adults has often led people to seek significance in their work. Giacalone \& Jurkiewicz (2003) define it as "a framework of organizational values evidenced in the culture that promotes employees' experience of transcendence through the work process, facilitating their sense of being connected to others in a ways that provides feelings of completeness and joy" (p. 13). According to Conger (1994) the yearning for meaning and "spirit at work" is in part fostered by the decline of traditional places of community (i.e., neighborhoods, churches, etc.) Thus, people may come to work with their spiritual needs less satisfied than was perhaps true of pervious generations who had access to numerous visible sources of community. The decline in traditional opportunities for community suggests that sources where people have sought to find not just belonging (community), but also meaning have declined. Thus, people may try to find both meaning and community at work (Vaill, 1998).

But a search for community and meaning at work can be difficult because the workplace has changed. For example, Vaill (1998) argues that workers may have traditionally been able to find meaning in the fact that their employment is secure, that their organizations have noble missions, or that their leaders are of the character which inspire employee commitment. However, in the more recent climate of organizational life, employment security no longer exists, leader turnover is high, much of the workforce is made up of temporary workers (Pfeffer \& Baron, 1988), and organizational values are suspect. In fact, there is mounting evidence that many people feel they work in places that hurt their spirits (Pfeffer, 2003; Terkel, 1985). Despite the challenges posed by the modern workplace, the need for meaning is still present in employees, and the workplace, where adults spend much of their waking hours, is still an opportune place to find meaning, or as Mirvis notes, find "something more" (Mirvis, 1997, p. 198).

This theme - the search for meaning - is also noted in the call of Mitroff et al. (1994) for "radical surgery" on organizations where meaning is found in moral causes. For example, they propose that organizations should recognize the spiritual dimension of organizational life and the search for meaning will unfold as the day-to-day affairs of the organization address the larger problems of humanity:

"By discussing the spiritual sides of organizations, we are not promoting an official "company religion" or an unqualified endorsement of one of the world's traditional religions or sects. Rather, we are talking about the greater moral purpose and obligation of every organization to contribute to the solution of world problems" (1994, p. 17).

The view of Mitroff et al. (1994) on the meaning at work takes a humanistic/social responsibility direction but, it is based in the notion that people and organizations want and need to be engaged in matters of importance in a context larger than economic matters. 
Echoing this theme of the search for meaning, Beyer (1999) argues that spirituality has two components - meaning and belonging:

\footnotetext{
"Because humans are meaning-seeking animals, they seek meaning in their work. Because they are social animals, they also seek a sense of belonging to social groups through their work. These two intangibles-meaning and belonging-enhance the inner lives of individuals and give their work a spiritual dimension" (Beyer, 1999, p. 1 ).
}

Beyer's enlarging the definition of spirit at work to include belonging is consistent with the view of Conger (1994) that spirituality, in the workplace or anywhere else, is an effort "to see our deeper connections to one another and to the world beyond ourselves" (1994, p. 15).

Ashmos \& Duchon (2000) continue with the themes of meaning and belonging when they discuss the components of a spiritual work place. First, spirituality at work means recognizing that workers are spiritual beings; they have an inner life where the need for meaning is addressed. Second, spirituality at work is about more than just the inner nature of workers, but also about what Beyer (1999) refers to as the need for belonging, for being part of a community. Finally, spirituality at work includes the notion that people's needs for meaning can be achieved through meaningful work. Thus, in this article, we use the Ashmos \& Duchon (2000, p. 137) definition of spirituality at work: "the recognition that employees have an inner life that nourishes and is nourished by meaningful work that takes place in the context of community." Each of the three parts of this definition - inner life, meaningful work, and community - can be understood in the context of similar-yet not the same-established constructs in the organization's literature: self-concept, job enrichment, and organizational climate. Reviewing the entire literature on each of these constructs would go beyond the bounds of this article. However, the intent is to show how the particular dimension of spirituality at work has conceptual roots in a similar organizational behavior notion, and thus deserves attention in the organization's literature.

\subsubsection{Inner life}

People bring their whole selves to work, and increasingly we see that the whole self includes the spiritual self. Dehler \& Welsh (2003) describe the changing nature of work as "people in the new workplace bring their whole selves to their jobs - including their heart and soul" (p. 118). Vaill refers to inner life it as "the feeling individuals have about the fundamental meaning of who they are, what they are doing, and the contributions they are making" (Vaill, 1998, p. 218). A CEO participant in a graduate course on "Spirituality for Business Leadership" taught by Andre Delbecq put it this way, "At the root of the connection between spirituality and business leadership is the recognition that we all have an inner voice and it is the ultimate source of wisdom in our most difficult business decisions" (Levy, 2000, p. 130). Thus, an important dimension of spirituality at work is the notion that employees have spiritual needs (i.e., an inner life), just as they have physical, emotional, and cognitive needs, and these needs don't get left at home when they come to work.

The existence of an inner life is related to two organizational behavior constructs: individual identity and social identity. Individual identity is part of a person's self-concept, or inner view of themselves, and the expression of that inner life is, in part, an expression of social identity. The self-concept theory of Shamir (1991) provides a useful framework for the consideration of "inner life" by arguing that congruence between one's inner self-concept (i.e., inner life) and one's work leads to greater motivation. His self-concept approach is based on five assumptions: (1) humans are not only goal-oriented, they are also expressive of feelings and self-concepts; (2) 
people are motivated by internal guides to enhance their self-esteem and self-worth; (3) people are motivated to retain and increase their sense of self-consistency (they derive a sense of meaning from a sense of unity of their self-concept and continuity among past and present and future behavior); (4) self-concepts are composed in part of identities which are motivating according to their salience (the more salient an identity such as a spiritual identity, the more motivating it will be, particularly when the work situation is seen as an opportunity to perform in terms of that identity); and (5) self-concept based behavior is not always related to clear expectations or to immediate and specific goals, i.e., behavior is often guided by imagined possibilities and "faith" (Shamir's word).

Thus, self-concept theory suggests that a job is motivating when there is a high level of congruence among the job, its context, and the person's self-concept. People whose self-concept includes a spiritual dimension will be motivated if their work context enables expression of their spiritual identity. Note that this does not suggest that such an opportunity will be motivating for everyone. As Shamir (1991) points out, some people are more instrumental than expressive and some people may not have crystallized a sense of self-concept. Thus, work can be motivating for an individual if it affirms his/her identity, i.e., an individual prefers work that is compatible with one's self identity (Leonard et al., 1995; Carlisle \& Manning, 1994; Manning \& Robinson, 1985; Shamir, 1991).

The notion of inner life is related to individual identity which Shamir's self-concept theory helps explain, and also to social identity which occurs through group membership -in this case in a work unit or organization. That is, individuals require a larger social context or group in order to completely understand and express themselves. For example, Ellemers, de Gilder, \& Haslam (2004) argue that employees who identify with their work unit can be energized when circumstances enhance the salience of common identity. Thus, a work unit that enables one's spiritual identity can energize the group. Further, others have suggested that belonging to a social group, i.e., to an organization, shapes one's self-concept (Ashforth \& Mael, 1989; Dutton et al., 1994; Kramer, 1991; Tajfel \& Turner, 1985). Individuals' identities are formed in part by how they believe others view the work unit or organization to which they belong (Dutton \& Dukerich, 1991). But an individual's social identity at work likely is not derived just from the "organization," but, as Ashforth \& Mael (1989) point out, the subunit where one works everyday may be an even more powerful determinate of social identity than the larger organization. The argument is that an individual's self-concept is shaped by the knowledge that he/she is part of a work unit. Fry (2003) refers to this in a theory of spiritual leadership as membership.

Workplace spirituality can be viewed, then, as a consequence of the self-concept at work and the social identity that is derived from work unit membership. If individuals define themselves as spiritual beings who have an inner life-even at work - and they belong to a work unit whose central, enduring character embodies (or at least permits) this definition, the work unit identity will thus provide an opportunity for expression of inner life.

\subsubsection{Meaningful work}

The second component of workplace spirituality embodies the notion that people seek meaning at work. This is not new since, for example, Etzioni (1995) reminds us what social psychologists have long argued - that work has meaning for people far beyond the material rewards commonly associated with work. For example, when a sample of people who were employed 
either full or part-time were asked in a 1987 Gallup poll whether or not they would continue working if they won $\$ 10$ million in the lottery, 59\% of those polled said they would continue to work (Gallup, 1998:p. 209). Other studies, such as that by Learner (1996) indicate that workers want their day-to-day jobs to seem connected to a larger purpose in life. As Pfeffer puts it, "Many people seek not only competence and mastery in their work but also to do work that has some social meaning or social value" (p. 6, 2002). Fry (2003) refers to this as giving people a sense of calling through meaning, in particular, meaning at work.

The "meaningful work" component of workplace spirituality has some roots in the job design literature although as we use it here goes beyond the notions associated with the job design literature. Job design has been defined as the "manipulation of the content, functions, and relationships of jobs to accomplish organizational purposes and satisfy the needs of job holders" (Szilagyi \& Wallace, 1987, p. 149).

Rooted in the principles of scientific management, initially job design focused on the importance of job specialization as a method for improving worker productivity. A negative reaction to job specialization, which created "little jobs" that were boring for workers, was observed, and so job design adherents developed job rotation and job enlargement as solutions to the problem of boredom at work (Lawler, 1973). However, rotating workers among boring jobs didn't make each job less boring and job enlargement simply gave workers more to do (Guest, 1957). Thus a shift occurred in approaches to job design with the introduction of notions of job enrichment such that the worker's psychological needs were considered as important as his/her physical or safety needs. Worker satisfaction, responsibility, autonomy, and achievement became important factors in the consideration of worker motivation and performance (Herzberg, 1974).

Job enrichment's initial promise, however, proved to be difficult to implement, and so revisions of the approach were offered (Hackman \& Lawler, 1971; Hackman \& Oldham, 1976) which focused attention on matching task characteristics and worker needs. Hackman \& Oldham (1980), in particular, have argued that meaningful work is one of the key features of a productive work environment. One of the core psychological states of their Job Characteristics model is termed "Experienced Meaningfulness." That is, the employee must perceive his/her work as worthwhile or important by some system of values s/he accepts. Individuals experience meaningful work to the extent they have an opportunity to perform activities that challenge their skill and use diverse abilities (skill variety), are able to complete a "whole" or identifiable piece of work (task identity), and the extent to which the job is see to have a substantial impact on the lives of others (task significance).

More recently, the new domain of positive organization scholarship (Cameron, Dutton \& Quinn, 2003) speaks directly to the idea of meaningful work. For example, Wrzesniewski \& Dutton (2001) point out that the meaning of work historically has been argued to be the product of one of three forces: 1) the work environment that affects how individuals derive meaning from work; 2) individual attributes and characteristics that affect the kinds of meanings assigned to work (Roberson, 1990); and 3) the social environment that helps people interpret the meaning of their jobs (Salancik \& Pfeffer, 1978). Wrzesniewski \& Dutton (2001) contend that individuals play an active role in creating the meaning of their work, through job crafting, that is, through small changes they make in task, relational and cognitive boundaries of the work. Pratt\& Ashforth (2003) argue that meaningfulness is fostered by meaning in work (attributes of the job) and meaning at work (membership and belonging). The important point, from the organization literature is that organization scholars have long recognized that people derive meaning from their 
work and, we contend, that because the search for meaning is what defines us as spiritual beings, meaningful work and workplace spirituality are intertwined.

Others, outside the field of management and organization studies have also noticed a connection between work and spirit. For example, theologian Matthew Fox writes about the spirituality of work:

Spirit means life, and both life and livelihood are about living in depth, living with meaning, purpose, joy and a sense of contributing to the greater community. A spirituality of work is about bringing life and livelihood back together again." (Fox, 1994, p. 2).

Thus, a conceptualization of spirituality at work must include, not only the recognition that individuals have inner lives that push them towards a search for meaning, but that part of the search for meaning is satisfied by meaningful work. This idea is raised in Mirvis' question: "What are organizations doing today to help people meet their meaning needs in the workplace?" (Mirvis, 1997, p. 199). We draw on the job design literature to ground the notion of meaningful work but go beyond the job design/job enrichment focus on meaningful tasks and jobs. Meaningful work is about cognitively meaningful tasks but it is also about work that creates a sense of joy (Wrzesniewski, 2003), which connects workers to a larger good and to things viewed by the worker as important in life (Giacalone \& Jurkiewicz, 2003). Leaders, according to Bennis (1999,) are responsible for creating a meaningful workplace:

People not only search for meaning in life, they also search for meaning in work. Is there such a thing as a meaningful workplace? If so, how does it look and feel? And what can leaders do to create it?" (Bennis, 1999, p. 44).

\subsubsection{Belonging to a community}

The third dimension of the definition of Ashmos \& Duchon (2000) on spirituality at work has to do with the notion that as spiritual beings people live in connection to other human beings. We use the word "community" here similar to Bellah, Madsden, Swinder, \& Tipton (1985), McMillan \& Chavis, (1986), and Mirvis (1997), and mean to include the notions of sharing, mutual obligation and commitment that connect people to each other. Our notion of community is also similar to the notion of Dutton (2003) on "high quality connections," that is, connections that are life-giving and not life-depleting (Dutton \& Heaphy, 2003). We see a spiritual work place as lifegiving. Also, Pfeffer (2003) refers to management practices that build as well as destroy the sprit, and we contend that belonging to a community is part of what builds the spirit at work. Mirvis writes, "Work itself is being re-discovered as a source of spiritual growth and connection to others," (Mirvis, 1997, p. 193). Weisbord writes, "We hunger for community in the work place and are a great deal more productive when we find it." (Weisbord, 1991, p. xiv).

In his examination of management practices that build or hurt the spirit, Pfeffer (2003) notes that an "important dimension that people value at work is being able to feel part of a larger community or being interconnected" (p. 7, 2003), and there are management practices that build the spirit. The idea that people want to belong at work is not a new idea to management thought as a number of management scholars have commented on this (Alderfer, 1972; McClelland, 1961; Maslow, 1954; Pratt \& Ashforth, 2003). Similarly, Fry (2003) builds this idea, referred to as membership, into a theory of spiritual leadership. However, it is important to recognize that belonging, i.e., being part of a community, can now be seen as part of what is required of a spiritfriendly work environment. 
More than simply being present in a community, however, an individual must identify him/ herself as an integral part of the community in order for the community's benefits to be realized, For example, Mitchell, Holtom, Lee, Sablynski \& Erez (2001) use the term job embeddedness to describe the influences of employee retention. Being embedded, and thus less likely to voluntarily leave a work setting, means having links to other people at work, the workplace community fits with other aspects of an employee's life spaces, and the "cost" or sacrifice required for leaving the community is high. The work of Mitchell, et. al. (2001) showed that when people feel embedded in a community at work they are much less likely to leave. The links to a community are an expression of social integration (O'Reilly, Caldwell, \& Barnett, 1989).

When individuals feel part of a work community and identify themselves with that group's purpose, it is only then that the increasingly complex work of contemporary organizations can be achieved (Bennis, 1999). Leaders are people who understand the basic spiritual need that people have to be part of a community and are successful at creating such a community at work.

The longing for community is born in all of us. Too few corporate leaders understand the depth of our craving to be part of something larger, and even fewer understand how to tap that longing to turn individual workers into a cohesive, productive group" (Bennis, 1999, p. 47).

\section{Spirituality at work, work unit performance, and leadership}

We have argued that the three components of work place spirituality identified by Ashmos \& Duchon (2000) have theoretical foundations in the management literature. That is, an inner life can be nourished by meaningful work in a larger context of community. A workplace where these spiritual needs - for an inner dimension to life, for meaningful work and for community are recognized and enabled is a workplace with a unique kind of climate a kind of spirit-friendly climate.

\subsection{Work unit spirituality and work unit performance}

The notion of workplace spirituality is based on the idea that members of a work unit have spiritual needs and when these needs are acknowledged the work unit has a unique kind of climate. Although an organization as a whole can be said to possess a unique character or identity (Dutton \& Dukerich, 1991), climate is a more particularized set of attitudes, values, and shared beliefs that shape a work unit (Ferris et al., 1998). Burke \& Litwin (1992) suggest that climate is a psychological state-a set of perceptions that workers have about the local work unit, how it is managed, and how workers relate to each other.

Thus, within the larger context of an entire organization with its particular character, individual work units will exhibit variation, or climate differences. Some climates will be more spiritfriendly than others. Burke \& Litwin (1992), for example, view climate as one of the "transactional" factors that contribute to motivation, which in turn affects performance. Others, such as Ostroff (1992), Ryan, Schmitt \& Johnson (1996), and Schmit \& Allschied (1995) have found relationships between specific kinds of climates, such as a climate for customer orientation (Rogg, Schmidt, Shull \& Schmit, 2001) and various performance measures. Day \& Bedian (1991) found that climate interacts with work orientation to predict employee job performance. 
While the climate literature is an extensive literature and to review it in its entirety is beyond the scope of this study, it is important to note that organizational climate, e.g., aggregate level, has been distinguished from psychological climate, e.g., individual level, (James \& James, 1989; James \& McIntyre, 1996). Within a single organization, several different psychological climates may exist, in part, as a function of the work unit, the values of its individual workers as well as the work unit leaders. We view workplace spirituality as a particular kind of psychological climate in which people view themselves as having an inner life that is nourished by meaningful work and takes place in the context of a community. Work units that can be characterized by a high degree of workplace spirituality are ones where workers are aligned with the climate. When this happens we contend the work unit will experience greater performance outcomes.

Fry (2003) argues that when organizations engage in "high-commitment workplace spirituality practices" individuals and organizations will benefit. More specifically, Giacalone \& Jurkiewicz (2003, p. 9) suggest that "spiritually-based organizational cultures are the most productive," while Mitroff \& Denton (1999) report that employees who viewed their organizations were "more spiritual" also believed their organizations were "more profitable." Wrzesniewski (2003) found that employees who derive the most meaning from their work, i.e., feel called to their jobs" experience higher job satisfaction and because job satisfaction is often linked to performance, there is like a relationship between work performance and workers who see their work as "calling." We expand on her limited findings about meaningful work and build on the theoretical arguments above to suggest that when work unit members report high recognition of having an inner life, when members report a strong sense of belonging to a community, and when members report a high degree of meaning in their work, we expect the overall work unit performance to be high.

\subsection{Leadership and work unit spirituality}

The role of leaders in nurturing workplace spirituality is beginning to emerge. For the purposes of this research we call on Kouzes \& Pozner (1987) definition of leadership as "the art of mobilizing others to want to struggle for shared aspirations" (p. 30). Ellemers et al. (2004) argue that successful leaders motivate their groups by creating a sense that the leader embodies a positive social identity the entire group has in common. (i.e., the shared aspiration of expressing a spiritual self), and that this collective identity motivates the optimization of collective performance.

That spirituality might be part of what makes leaders effective is gaining credibility. For example, well-known leadership scholars, such as Bennis (1999) are calling for the need for leaders to "follow your spirit" (p. 17) and create meaningful work for others as well as a sense of community at work. Pfeffer (2003) has called for organizational leaders to assume management practices that enrich the human spirit by building values. Vaill speaks of the role of leaders in responding to employees' needs " to find spiritual meaning in their organizations" (Vaill, 1998, p. 173.) Fry (2003) has advanced a theory of spiritual leadership by drawing on the extensive leadership literature (see Fry, 2003 for a complete review) as well as the early work on workplace spirituality.

At the root of much of this work is the idea that when leaders value meaning at work and value connections with others, it is likely then that the workplace will be characterized by meaningful work and a sense of community. The theory of Fry (2003) on spiritual leadership defines spiritual leadership as "comprising the values, attitudes, and behaviors that are necessary to intrinsically motivate one's self and others so that they have a sense of spiritual survival through 
calling and membership" (Fry, 2003, p. 3). Dutton (2003) directly links the life-giving connections in organizations that she argues are important for organizational success directly to the behaviors of leaders:

A leader's every move affirms or disconfirms the potential for building high-quality connections.... A leader with this kind of relational attentiveness can play a key role in sustaining and repairing the connective tissue of a workgroup, department, or organization.( Dutton, 2003, p. 164).

Wrzesniewski (2003) argues for a "dynamic view [of work] in which both the individual and the system act together to determine the types of meaning that will be experienced" (Wrzesniewski, 2003, p. 300). Bolman \& Deal (2003) make this connection between the system and the individual even more explicit through the role of spiritual leaders who feel their own work is significant and thus are able to help their subordinates find meaning at work. Because leadership is an important element of "the system" that acts together with the individual to determine meaning and because leaders can be transformational, (Kets de Vries, 1998; Tichy \& Devanna, 1986) we believe that when leaders value inner life, meaningful work, and being part of a community, it is more likely that the employees who report to them will value these ideas as well.

\section{Methods}

The goal of this exploratory study was to examine "work unit" spirituality, and explore the possible relationship between work unit spirituality and work performance. The results allowed us to make inferences about the role of leadership in a spirit-friendly work environment and develop propositions for testing in subsequent research.

\subsection{Organizational setting: Determining the sample}

The research was conducted in a large healthcare network in the Southwestern United States. Although it is a straightforward matter to identify work units from an organizational point of view (e.g., emergency room, medical/surgery unit, cafeteria, housekeeping, etc.), from a research point of view it is not clear how many informants (or which informants) are required before one can be confident that the characteristic attitudes in that "work unit" have been captured. We applied a strict criterion for this study: we included only those work units from which every member of the staff completed the Meaning and Purpose at Work questionnaire (see below). We were able to identify eight such intact work units from data collected as part of an ongoing study inside the larger healthcare network. One unit was an EMT operation located in a rural area; one unit provided health care to home-bound patients; one unit provided hospital care for medical/surgery patients; and five units provided emergency room/intensive care services in five different hospitals in the same metropolitan area. We focused on the six units that provided patient care at a hospital.

The present study thus reports data from six intact work units from five different hospitals, all belonging to the same large healthcare network in the Southwestern United States. For purposes of comparability, the five emergency room/intensive care units are responsible for addressing the same kinds of emergency healthcare needs in their area. The medical/surgery unit provides ongoing care for hospitalized patients, and while the daily work-life in the unit does 
not have the physical and emotional intensity of an emergency room, the staff does provide care that is medically comparable. All six units must also operate within the same policies of the parent network. Belonging to the same parent organization, and the similarities in medical work processes do not, however, ensure similarities in leader-styles, employee attitudes, or overall unit performance.

The units ranged in size from 6 to 35 personnel, with an average size of 18. Some 85\% of the 108 informants are female, and the informants, on average are 38 years old, have been members of their work unit 6 years. Some $10 \%$ of the informants have graduate degrees, $37 \%$ bachelor's degrees, $26 \%$ associate's degrees, and $20 \%$ are high school graduates. There were no significant differences among the units' informants in terms of age, organizational tenure, or educational level. The informants completed the Meaning and Purpose at Work questionnaire (see below) during the time period of February-April, 2000.

\subsection{Measures of workplace spirituality}

Ashmos \& Duchon (2000) have defined spirituality at work as the recognition that employees have an inner life that nourishes and is nourished by meaningful work that takes place in the context of community. Thus, spirituality at work as it applies to individuals has three components: the inner life, meaningful work, and community. The Meaning and Purpose at Work questionnaire reported by Ashmos \& Duchon (2000) captures informants' personal experience; that is, their perceptions of their own inner life, the meaningfulness of their work, and their individual sense of community at work. The questionnaire also addresses work unit-level issues by capturing the informants' observations of their work unit as a whole (in contrast to how things affect them personally) as a community (Work Unit Community) and as possessing meaning (Work Unit Meaning).

The current study uses the three individual and two work-unit level measures for spirituality at work reported by Ashmos \& Duchon (2000). That paper also reported instrument development and psychometric data (e.g., factor analyses, inter-item correlations, reliabilities, etc) for the scales based on a sample of 696 informants. Subsequent to the publication of that paper, Ashmos \& Duchon (2000) continued to collect data, and at present some 2033 informants from healthcare settings in six cities (five states) have completed the Meaning and Purpose at Work questionnaire. The factors (and their respective scales) have not changed as the sample size grew. The spirituality measure data for each work unit are presented in Table 1. See Appendix A for questionnaire items.

Table 1. Work unit spirituality means (and standard deviations) and performance scores

\begin{tabular}{|c|c|c|c|c|c|c|c|}
\hline & Community & $\begin{array}{l}\text { Meaning } \\
\text { at work }\end{array}$ & $\begin{array}{l}\text { Inner life } \\
\text { community }\end{array}$ & $\begin{array}{l}\text { Work unit } \\
\text { meaning }\end{array}$ & $\begin{array}{l}\text { Work unit } \\
\text { (rank) }\end{array}$ & $\begin{array}{l}\text { Quality } \\
\text { (rank) }\end{array}$ & Sensitivity ${ }^{\mathrm{a}}$ \\
\hline Unit $1 \mathrm{med} / \operatorname{surg} N=18$ & $4.84(.93)$ & $5.44(1.02)$ & $5.21(1.47)$ & $4.82(1.01)$ & $4.99(1.35)$ & $76.2(1)$ & $77.8(1)$ \\
\hline Unit 2 ER $N=6$ & $5.27(.27)$ & $5.11(.90)$ & $5.73(.62)$ & $4.63(.20)$ & $5.69(.48)$ & $73.3(2)$ & $71.2(2)$ \\
\hline Unit 3 ER $N=20$ & $5.73(.65)$ & $5.78(.63)$ & $5.97(.87)$ & $5.71(.71)$ & $6.05(.74)$ & $69.7(3)$ & $68.2(3)$ \\
\hline Unit 4 ER $N=14$ & $4.64(.90)$ & $5.04(.90)$ & $5.82(.98)$ & $5.20(1.98)$ & $4.76(1.28)$ & $67.4(4)$ & $66.2(4)$ \\
\hline Unit 5 ER $N=20$ & $4.66(1.08)$ & $4.91(.90)$ & $5.78(1.00)$ & $4.42(1.11)$ & $4.56(1.29)$ & $65.8(5)$ & $63.0(5)$ \\
\hline Unit 6 ER $N=35$ & $4.35(1.15)$ & $5.04(1.07)$ & $5.40(.97)$ & $3.98(1.28)$ & $4.35(1.52)$ & $59.5(6)$ & $58.2(6)$ \\
\hline
\end{tabular}

a. Represents percentage of patients who gave rating of either "Excellent" or "Very Good". 


\subsection{Performance measures}

We asked representatives of the healthcare network where the research was conducted to identify their most important indicators of performance. Rather than impose performance indicators that might reflect our view of performance (e.g., utilization of resources, turnover, employee performance ratings, etc.), we felt that using the network's indicator would better capture the network's view and understanding of their own performance. The healthcare network uses measures of patient satisfaction as the key indicator of work unit performance. Thus, the performance measures reported here are the measures of patient satisfaction collected by the healthcare network and used to assess work unit performance. The satisfaction measures are somewhat complex and subtle, and they require a detailed explanation.

Two types of patient satisfaction are routinely gathered by every work unit in the network: 1) patients' evaluation of overall quality of care (Quality); and 2) patients' evaluation of overall sensitivity of staff providing the care (Sensitivity). These patient attitudes are captured with a questionnaire that the healthcare network distributes to each patient. This questionnaire uses a 5-point Likert style scale where $5=$ excellent and $1=$ poor. The healthcare network counts the number of patients who respond with either a 5 (excellent) or 4 (very good) rating and reports these responses as a percentage (e.g., $60 \%$ of all patients gave either a 5 or 4 response on the questionnaire). The healthcare network routinely collects and summarizes these data. Table 1 reports the performance data for the units. Note that these performance data apply to each unit as a whole. That is, there is one Quality score and one Sensitivity score for each unit. The scores do not represent the performance of individual staff members within each unit. These data columns also report each unit's performance rank (see Table 1). Thus the sample reported below refers to the six work units.

\section{Results}

The concept of spirituality at work is in an early stage of development (Fry, 2003) and so we took an exploratory approach to the data. (Behrens, 1997). Moreover, the sample presented here is small, which presents analytical challenges. According to Behrens (1997) exploratory data analysis uses a visual exploration of data in order to find patterns. The patterns found can be used to develop propositions, hypotheses and models that can be tested in subsequent research efforts.

Figure 1 presents boxplots for the Sensitivity scores shown in Table 1, and Figure 2 presents boxplots for the Quality scores shown in Table 1. Boxplots (also known as box and whisker plots) were developed by Tukey (1977), as a way of presenting visually a great deal of information about data and also offering side-by-side comparisons.

The graphs in Figures 1 and 2 plot the spirituality variables on the vertical axes and the performance data on the horizontal axes. Each graph shows the data for all six work units. Each box (and its whiskers) within a graph shows the range of spirituality scores for a work unit. The box itself contains $50 \%$ of the data for a work unit. The upper edge of the box indicates the 75th percentile, while the lower edge indicates the 25th percentile. The range of the middle two quartiles is called the inter-quartile range. The median score for a work unit is represented by the heavy line in the box. The whiskers indicate minimum and maximum data points up to a distance 1.5 times the inter-quartile range. Outliers are shown as individual data points. For example, in Figure 1, the graph for Work Unit Community shows outliers for 

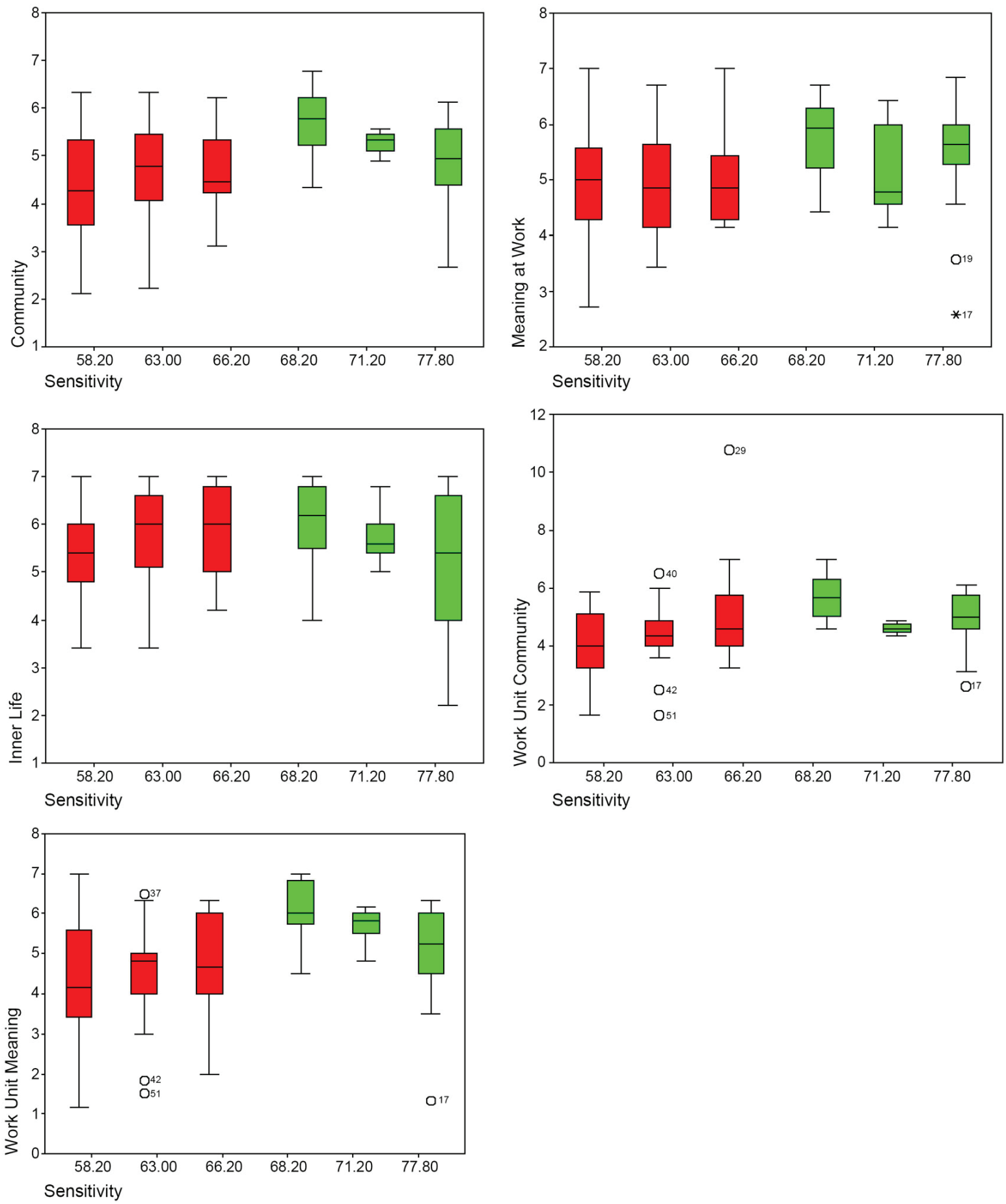

Figure 1. Box plots for spirituality variables for each work unit: plotted according to sensitivity score.

three of the work units. Thus, one can easily observe the location and spread of data for each work unit, gain some sense of the data's symmetry and skewness, see outliers, and see how each work unit compares to the others.

In looking at Figures 1 and 2 it may not appear at first glance that the spirituality variables vary dramatically across work units. A closer examination, however, reveals that the highest 

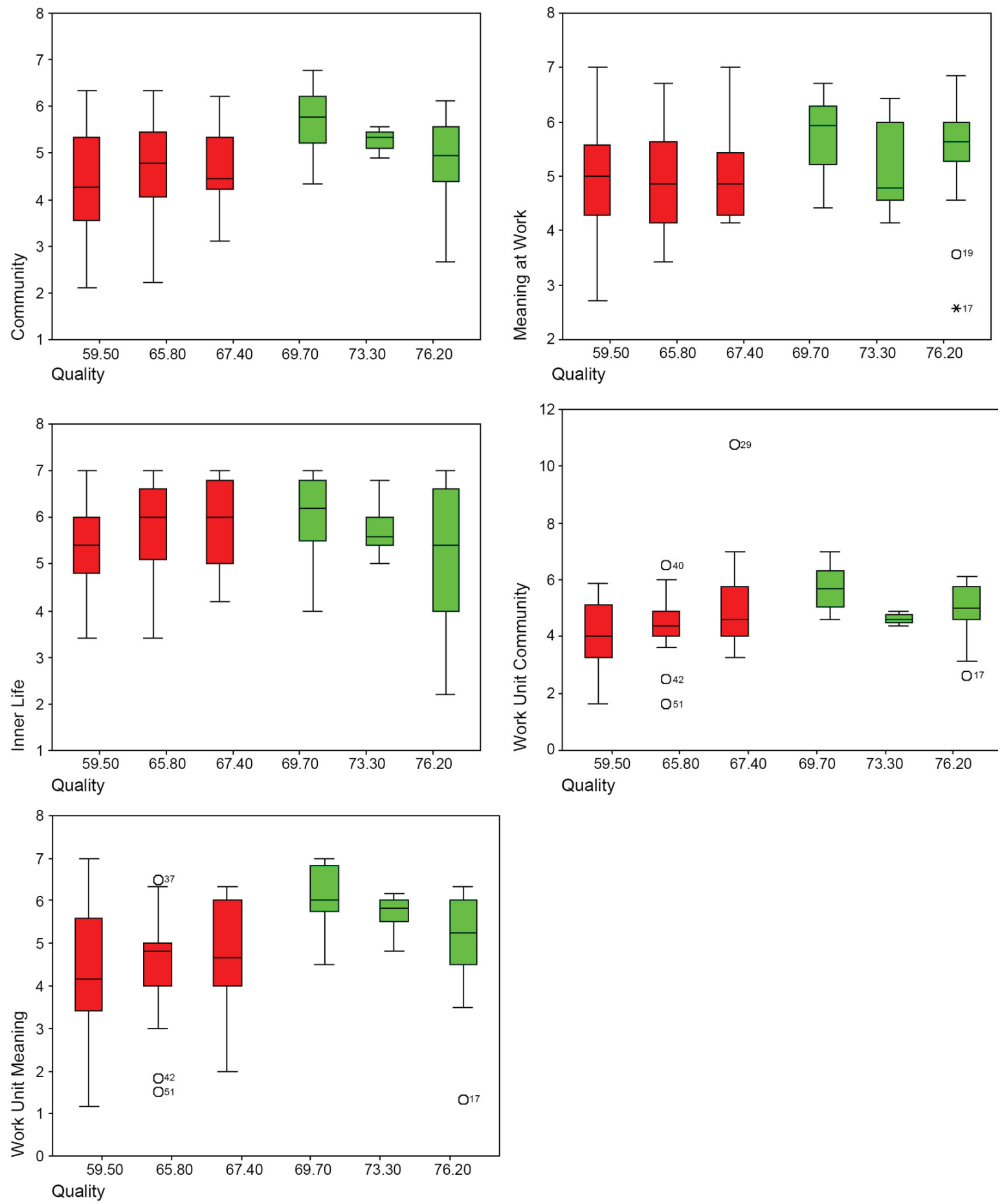

Figure 2. Box plots for spirituality variables for each work unit: plotted according to quality score.

performing unit has higher spirituality scores than the lowest performing unit. The exception are the scores for the Inner Life variable which appear to be the same across all units. The relationship between unit performance and spirituality scores is further suggested by the data in Table 2 which presents non-parametric correlations between spirituality scores and work unit per- 
Table 2. Correlations of spirituality means and unit performance scores

\begin{tabular}{|c|c|c|c|c|c|}
\hline & Community & Meaning at work & Inner life & Work unit community & Work unit meaning \\
\hline \multicolumn{6}{|l|}{ Quality score: } \\
\hline Kendall tau & $.47 x$ & $.55 x x$ & -.07 & $.48 x$ & $.60 \times x x$ \\
\hline Spearman rho & $.71 x x$ & $.73 x x$ & -.20 & .54 & $.77 \times x x$ \\
\hline \multicolumn{6}{|l|}{ Sensitivity score: } \\
\hline Kendall tau & $.47 x$ & $.55 x x$ & -.07 & $.47 x$ & $.60 \times x x$ \\
\hline Spearman rho & $.71 x x$ & $.73 x x$ & -.20 & .54 & $.60 x$ \\
\hline
\end{tabular}

$N=6$

$\mathrm{x}=p<.20 ; \mathrm{xx}=p<.15 ; \mathrm{xxx}=p<.10$

formance scores. The correlations (except for Inner Life) are positive and fairly robust, although none reach conventional levels of statistical significance because $n=6$.

Figures 1 and 2 also show that generally the top three performing units have higher spirituality scores than the bottom three performing units (as indicated by medians), with the exception of Inner Life. This observation is supported by the data in Table 3. Table 3 compares the average spirituality score for the top three performing units with the average spirituality scores for the bottom three performing units. When these data are subjected to a non-parametric Mann-Whitney test the top three performing units have, on average, higher spirituality scores than the bottom three units, with the exception of Inner Life.

Thus, overall although the sample is small $(n=6)$, graphical presentation of the data combined with follow-up non-parametric procedures suggest that there is a relationship between the spiritual climate of a work unit and its overall performance.

\section{Discussion}

People spend a good portion of their life at work and also derive a good portion of their social identify from work. With the decline in traditional sources of community - such as neighborhoods and membership in traditional church denominations - people seem to bring their needs for community to work. Thus, people increasingly place demands on the workplace for a sense of wholeness and connectedness.

Table 3. Comparison of spirituality means (and standard deviations) for three higher and three lower performance units

\begin{tabular}{llllll}
\hline & Community & Meaning at work & Inner life & Work unit community & Work unit meaning \\
\hline $\begin{array}{l}\text { Three higher } \\
\text { performance units }\end{array}$ & $5.30^{* * *}(.85)$ & $5.55^{* * *}(.86)$ & $5.63(1.17)$ & $5.23^{* * *}(.93)$ & $5.56^{* * *}(1.12)$ \\
$\begin{array}{c}\text { Three lower } \\
\text { performance units }\end{array}$ & $4.50(1.08)$ & $5.00(.98)$ & $5.60(.99)$ & $4.35(1.45)$ & $4.49(1.40)$
\end{tabular}

Statistically significant difference in scores between higher/lower performing work units when subjected to MannWhitney Test.

$* * * p<.001$ 
We agree with Fry (2003) that workplace spirituality is a construct that is in an early stage of development. Thus, while our data are obtained from only six work units, we use the data to ground theory and develop propositions regarding spirit at work. Although exploratory in nature, we provide some evidence in this study that work units whose climates enable a sense of community and enable a sense of meaningful work (i.e., work units that attend to the needs of the spirit) perform better than work units whose climates are less attentive to the needs of the spirit. That is, work places that enable the expression of the spirit perform better than those that are less spirit-friendly. The evidence we provide supports the belief articulated by the participants in the study of Mitroff \& Denton (1999) that when their organizations were more spiritual they thought it was likely that the organizations were more profitable. The important contribution we make here is to offer some empirical evidence using performance data that is not self-reported to support the increasingly frequent claims that a relationship between workplace spirituality and performance exists (e.g., Giacalone \& Jurkiewicz, 2003). Thus, we offer:

Proposition 1 Work unit performance will be associated with work unit spirituality. Work unit performance will be greater in work units that enable a spiritual (or spirit-friendly) climate.

Establishing that a spirituality-performance connection exists does not suggest how the connection occurs. Our argument is that spirit-friendly work units are enabled by leaders who possess a strong spirit-friendly orientation. Consider that the work units examined in this study do the same work, belong to the same systems, and thus have the same terms of employment, pay, benefits, etc. The individuals in the work units have the same education and work experience. Also, the scores for the Inner Life variable do not vary across the work units. We interpret this to mean that the individuals in the work units possess the same degree of awareness of their inner life. That is, each work unit has the same spiritual "raw material." But the sense of meaningful work (when they do the same work), and the same sense of community vary. The variability in these factors, we contend, is a function of the leader.

Table 4 shows that the leaders in the better performing units have higher spirituality scores than the leaders in the lesser performing units. This suggests to us an association between the spiritual energy of the leader and the spiritual climate of the work unit. Work units are spirit-friendly because the leader enables community and enables the realization of meaningful work.

Table 4. Comparison of spirituality means (and standard deviations) for supervisors in the three higher versus the three lower performance units

\begin{tabular}{llllll}
\hline & Community & Meaning at work & Inner life & Work unit community & Work unit meaning \\
\hline $\begin{array}{l}\text { Three higher } \\
\text { performance units }\end{array}$ & $5.68^{* *}(.66)$ & $5.83^{*}(.64)$ & $5.37(1.21)$ & $5.58^{* *}(.70)$ & $6.05^{* *}(.43)$ \\
$\begin{array}{l}\text { Three lower } \\
\text { performance units }\end{array}$ & $4.73(1.14)$ & $5.24(1.01)$ & $5.88(.98)$ & $4.55(1.39)$ & $4.69(1.46)$ \\
\hline
\end{tabular}

Statistically significant difference in scores between higher/lower performing work units when subject to $t$-tests. See Table 2 for ranking of groups. There are a total of 14 supervisors in the higher performing units and 11 supervisors in the lower performing units.

${ }^{* *} p<.01 ;{ }^{*} p<.05 ;+p<.10$ 
A leader enables a climate that allows the expression of an employee's spiritual self. The leader enables a spiritual "fit" in the work unit. Fit generally is an employee's perceived compatibility or comfort with an organization and with his or her environment (Mitchell et al., 2001). Mitchell et al. (2001) argue that the better the fit, the higher the likelihood that an employee will feel professionally and personally tied to (or embedded in) the organization. People who do not fit tend to leave the organization rapidly (cf: Chatman, 1991; O'Reilly et al., 1991). Having a good fit, of course does not guarantee better employee or work unit performance. But we would argue that good fit or alignment would more likely be associated with better performance, and poor fit would more likely be associated with lesser performance. "People thrive in community and function best when they share praise, comfort, happiness, and humor with people they like and respect...this kind of social support reaffirms a person's membership in a group with a shared sense of values." (Maslach \& Leiter, 1997 p. 415). All of this is a consequence of the leader's efforts; leaders who see themselves as spiritual entities.

The role of the leader as a key element in the spirituality-performance connection is addressed by the model of Fry (2003) on spiritual leadership. Fry argues that the spiritual leader is someone who motivates others by creating a shared vision of a long-term desirable future. The shared vision is achieved because the spiritual leader possesses and exhibits the values, attitudes, and behaviors that enable organizational members to experience a sense of calling in that their work life has meaning and makes a difference. Thus, the leader can both model the presence and importance of inner life, and s/he can help in clarifying an employee's sense of meaningful work. The spiritual leader also shapes a culture based on altruistic love (Fry, 2003) whereby the leader and the followers have genuine concern and appreciation for both themselves and others. The spiritual leader thus contributes to a heightened sense of community.

Therefore, we propose:

Proposition 2 Work unit spirituality will be associated with the leader's ability to enable the worker's inner life, sense of meaningful work, and community.

We should note, however, that a spiritual leader enabling a worker's expression of "inner life" can become problematic if the spiritual leader's enthusiasm or zeal is seen by the worker as coercive. This can happen when the spiritual leader's expression of spirituality conforms too rigidly to a particular belief system or religious doctrine. The spiritual leader can unintentionally create a hostile work environment when only the leader's form of inner life expression is accepted and "non-believers" (i.e., those preferring a different form) feel marginalized. The spiritual leader's enabling of a worker's inner life has to be undertaken in a work culture based on a norm of individual and collective tolerance and freedom. Robert Ouimet, for example, argues that a "full freedom" approach to work place spirituality is necessary to reconcile productivity and human well-being (see http://www.our-project.org).

\subsection{Proposed theoretical model}

In this study we use and develop the construct of Ashmos \& Duchon (2000) on workplace spirituality in our examination of the relationship between work unit spirituality and work unit performance, and we have made limited inferences in this study about the role of leaders in the development of a spirit-friendly workplace. Based on our evidence we propose a theoretical 


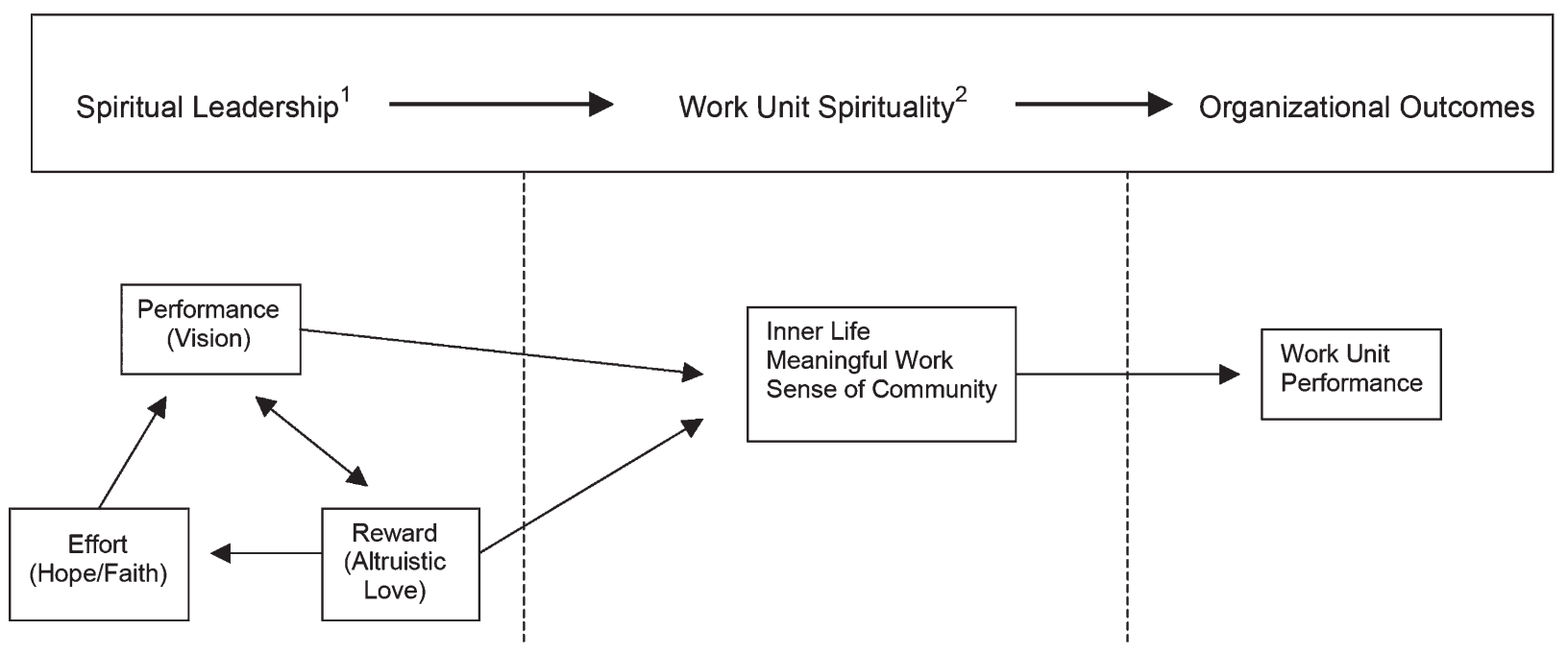

Figure 3. Theoretical model of spirituality at work.

model that can be used for more fully testing the relationship of spiritual leadership, workplace spirituality and work unit performance.

The definition of Fry (2003) on spiritual leadership represents the leadership component and the definition of Ashmos \& Duchon (2000) on workplace spirituality represents the work unit spirituality construct. The model of Fry (2003) argues that work place spirituality is positively associated with leaders who possess and exhibit the values, attitudes, and behaviors of spiritual leadership. This means developing a shared vision that taps into calling, developing a culture based in the values of altruistic love that taps into membership/community, and developing a sense of hope/faith that engenders a "do what it takes" attitude in pursuit of the work unit's vision. Spiritual leadership will shape a work unit that recognizes employees having an inner life and enables these employees to participate in meaningful work that takes place in the context of community.

Ultimately, the model suggests that these variables lead to enhanced work unit performance. (See Figure 3). This model should be seen as a basic, a starting point, because other attitudinal, motivational, and work climate variables could logically be added and so enhance the model's refinement. Our interest is in proposing an essential spirituality-performance link without which further model development would be irrelevant.

\subsection{Implications for research}

Organizational studies have largely not considered the spiritual dimension of human beings. From a variety of research streams, it has been established that people have emotional, cognitive and physical needs that affect behavior and performance at work. However, the spiritual needs of people at work have largely been ignored, at least in mainstream outlets for research. Our research leads us to believe that ignoring spirit at work may be shortsighted because ignoring spirit may mean ignoring a fundamental feature of what it means to be human. Thus, we suggest that more attention could be directed at understanding spirit at work, its features, and how 
it finds expression, because by enabling the expression of spirit we create workplaces that are receptive to the "entire" or whole person, and as such, may be more productive than workplaces where spirit is ignored. As Mitroff \& Denton (1999) learned people want to "be able to express and develop their complete self at work." (Mitroff \& Denton, 1999, p. 85).

As Giacalone \& Jurkiewicz, (2003) assert, the topic of workplace spirituality could benefit from a more scientific approach to its study than exists at present. The Ashmos \& Duchon (2000) measure of spirituality at work which we used has promise, but it is in an early stage of development and will have to demonstrate its utility for different settings and larger samples. The study reported here is a small sample study, and is limited because of that. The study reported here is also confined to a single work organization, although it is a large organization with work units that show variability in measures of both performance and spirituality.

Also, the research was conducted in a healthcare setting where it might be that the employees are sensitive (or open) to their spiritual selves because of social values of healthcare professions. In this study we examined intra-organizational differences in spirituality and did not make comparisons across organizational types. Further research on a larger number of organizations in another industry would help strengthen the findings reported here. Additionally, research on workplace spirituality could be enhanced through qualitative studies of a few spiritually friendly climates in order to enrich the measures of workplace spirituality that are offered here. Our measure has focused on inner life, meaningful work, and community, but there may, in fact, be other dimensions that should be added to the conceptualization offered here.

We have argued here that spirit-friendly work climates enable expression of the "whole" person and thus have the potential to be more productive work environments. From this study we also draw some initial conclusions about work unit leaders and the extent to which a spiritfriendly climate is created or enhanced by the behaviors and attitudes of leaders. Although we cannot speak to causality, our data suggest something about co-varying attitudes. We observed that leaders in spirit-friendly work units had a stronger sense of spirit than leaders in less spiritfriendly units. Employees of spirit-friendly work units seemed to share more strongly the leader's views. We would argue that it is not a coincidence that the scores for supervisors and the scores for the work units as a whole show the same patterns. It seems likely that the supervisors (leaders) in the spirit-friendly (and better performing) units are doing something different, something that enables a spirit-friendly workplace. They may, in fact, be engaging in management practices that build rather than hurt the spirit (Pfeffer, 2003).

Do leaders influence their subordinates to see themselves as spiritual beings? Do leaders create meaningful work for themselves and others? Do leaders build a sense of community at work? We think the answer to these questions is most likely "yes." But further research on workplace spirituality would benefit from trying to capture specific leadership styles (i.e., differing managerial and leadership behaviors) and associating them with workplace spirituality. For example, it seems likely that leaders identified as transformational leaders would be associated with work units that are spiritually friendly because, by definition, they are paying attention to boundary expanding issues. By enabling expression of the whole person they are tapping into motives and modes of behavior that are very powerful because they spring from the essence of what it means to be human. Transactional leaders, in contrast, are paying attention to boundary-satisfying externalities that ensure what has always been done will continue to be done. These and other such questions need to be explored empirically. 


\subsection{Implications for leaders}

Our study also suggest some implications for behavioral practices of leaders in organizations. If work unit performance is better when workers feel that they are participating in meaningful work (this interpretation is made cautiously given the size of our sample), then leaders should pay attention to the importance of creating meaningful work for others. In contrast to the job design approach to task significance, here we are talking about a broader notion of creating a sense of joy (Fox, 1994; Giacalone \& Jurkiewicz, 2003;) at work. The implication we draw from our findings support the call of Bennis (1999) for leaders to "imbue even the most mundane work with meaning and turn even tedious activities into inspirational missions that people rally around" (p.43).

There are no easy prescriptions for how leaders go about creating spiritually friendly workplaces, in part because the nature of contemporary organizations is quite different from that of traditional organizations of previous decades. Modern organizations are becoming less rigid and more fluid in their design because the modern world seems to reward speed and adaptability. Organizations and the people who comprise them will be rewarded for learning, growing, and changing rather than completing the same narrowly defined task over and over. Thus, it seems likely that leaders will need to be comfortable with a much more fluid, dynamic work environment which means that what constitutes "meaningful work" will itself change. Pfeffer (2003) argues that people seek "interesting work that permits them to learn, develop, and have a sense of competence and mastery [and] meaningful work that provides some feeling of purpose" (p. 32). Effective leaders will be those who help subordinates find these characteristics in their work.

Similarly, our findings suggest that work unit performance is better when workers feel part of a community. Thus, it is likely that effective leaders will encourage connections among people at work and who keep people connected through a climate of trust. Traditional, bureaucratic views of organizing work require complete (narrow) job descriptions and voluminous operating procedures that create specializations which essentially isolate people from each other. It is often common to find organizational mission statements that espouse the value of collectivity and shared purpose, yet daily procedures and rules that separate people from each other. This kind of disparity between the organization's talk and its walk breeds distrust and distrust destroys community. Modern, fluid organizations need to find ways of letting go of procedures so that workers have opportunities to self-organize (i.e., create community) in ways they find meaningful to the nature of the work. Given our finding of a greater sense of community in high performing work units it is important that leaders who want to improve unit productivity engage in community building efforts.

Dutton (2003) suggests four specific qualities of leaders who help sustain high quality connections, which is similar to our notion of belonging to a community at work: a leader is personally open, is relationally attentive, uses language and stories to help relationships grow, and has a positive image of the future. These practices would contribute to strengthening the spiritual dimension of a work unit.

We also found that the leaders of high performing units score higher on a measure of spirituality at work, suggesting that there may be specific management practices that are associated with spiritually health work units. While our study did not uncover these empirically, our findings lend support to the leadership practices that Pfeffer (2003) suggest for helping build the spirit at work: 
- Emphasize mission and values over shareholder profits.

- Encourage autonomy and decision making responsibility.

- Use self-managed teams.

- Use collective forms of reward and recognition.

- Let people be who they are and use and develop their gifts and skills.

- Provide a way for people to fulfill their family and other social obligations.

- Drive fear and abuse out of the workplace.

Given the importance of work to most people and the amount of time we spend at work, the results from this study showing a relationship between work unit spirituality, work unit performance, and leadership attitudes towards spirituality, it is time for organizational researchers as well as organizational leaders to take the issue of workplace spirituality seriously. The definition of workplace spirituality used in this study offers leaders some avenues for keeping the work unit from becoming "dispiriting places... with dispiriting leaders-leaders whose impact blocks the spirit of others, setting people against each other and souring the climate of the organization" (Vaill, 1998, p. 220). Clearly, leaders have a responsibility for nurturing the spirit by helping their subordinates be open to their inner lives, by helping them find meaning in their work, and by strengthening a sense of community in the workplace. Such leaders Fry (2003) would call spiritual leaders, and such leaders, we contend, will find themselves managing work units that are both more satisfying for its members and more productive in terms of the larger organization.

Acknowledgments - The authors thank Seton Cove in Austin, Texas, for the development of the Finding Meaning and Purpose at Work questionnaire from which the measure of workplace spirituality was determined. This work was substantially improved by comments from three anonymous reviewers for The Leadership Quarterly, Jody Fry and Jerry Hunt.

\section{Appendix A. Questionnaire items}

\section{Community $a=.857$}

\begin{tabular}{llll} 
Item & Mean & Std. dev. & Range \\
\hline I feel part of a community in my immediate workplace (department, unit, etc.). & 5.30 & 1.56 & $1-7$ \\
My supervisor encourages my personal growth. & 4.61 & 1.87 & $1-7$ \\
I have had numerous experiences in my job which have resulted in personal growth. & 5.41 & 1.43 & $1-7$ \\
When I have fears I am encouraged to discuss them. & 4.30 & 1.58 & $1-7$ \\
When I have a concern I represent it to the appropriate person. & 5.52 & 1.12 & $2-7$ \\
At work we work together to resolve conflict in a positive way. & 4.75 & 1.62 & $1-7$ \\
I am evaluated fairly here. & 4.96 & 1.66 & $1-7$ \\
I am encouraged to take risks at work. & 3.64 & 1.76 & $1-7$ \\
I am valued at work for who I am. & 4.78 & 1.75 & $1-7$ \\
\hline
\end{tabular}


Meaning at work $a=.864$

Item

\begin{tabular}{lll} 
Mean & Std. dev. & Range \\
\hline 5.42 & 1.16 & $2-7$ \\
5.27 & 1.19 & $2-7$ \\
4.65 & 1.57 & $1-7$ \\
5.59 & 1.22 & $1-7$ \\
4.81 & 1.62 & $1-7$ \\
5.22 & 1.41 & $1-7$ \\
5.51 & 1.13 & $1-7$
\end{tabular}

I experience joy in my work.

I believe others experience joy as a result of my work.

My spirit is energized by my work.

The work I do is connected to what I think is important in life.

I look forward to coming to work most days.

I see a connection between my work and the larger social good of my community.

I understand what gives my work personal meaning.

$$
\text { Inner life } a=.822
$$

\begin{tabular}{llll} 
Item & Mean & Std. dev. & Range \\
\hline I feel hopeful about life. & 6.27 & .91 & $3-7$ \\
My spiritual values influence the choices I make. & 5.90 & 1.34 & $1-7$ \\
I consider myself a spiritual person. & 5.79 & 1.40 & $1-7$ \\
Prayer is an important part of my life. & 4.96 & 1.99 & $1-7$ \\
I care about the spiritual health of my co-workers. & 5.10 & 1.64 & $1-7$ \\
\hline
\end{tabular}

\section{Work unit community $a=.871$}

Item

\begin{tabular}{lll} 
Mean & Std. dev. & Range \\
\hline 3.91 & 1.56 & $1-7$ \\
4.68 & 1.46 & $1-7$ \\
4.90 & 1.65 & $1-7$ \\
4.85 & 1.47 & $1-7$ \\
4.64 & 1.70 & $1-7$ \\
4.66 & 1.41 & $1-7$ \\
4.57 & 1.77 & $1-7$ \\
2.90 & 1.92 & $1-7$ \\
\hline
\end{tabular}

\section{Work unit and meaningful work $a=.914$}

\begin{tabular}{|c|c|c|c|}
\hline Item & Mean & Std. dev. & Range \\
\hline I feel positive about the values of my immediate work unit. & 4.87 & 1.53 & $1-7$ \\
\hline My immediate work unit has a conscience. & 4.92 & 1.66 & $1-7$ \\
\hline I feel connected with my immediate work unit's goals. & 4.88 & 1.69 & $1-7$ \\
\hline My immediate work unit is concerned about the health of those who work here. & 5.11 & 1.71 & $1-7$ \\
\hline I feel connected with the mission of my immediate work unit. & 4.96 & 1.63 & $1-7$ \\
\hline I feel positive about my future with my immediate work unit. & 4.80 & 1.78 & $1-7$ \\
\hline
\end{tabular}

\section{Community $a=.857$}

I feel part of a community in my immediate workplace (department, unit, etc.).

My supervisor encourages my personal growth.

I have had numerous experiences in my job which have resulted in personal growth.

When I have fears I am encouraged to discuss them.

When I have a concern I represent it to the appropriate person.

At work we work together to resolve conflict in a positive way.

I am evaluated fairly here.

I am encouraged to take risks at work.

I am valued at work for who I am. 
Meaning at work $a=.864$

I experience joy in my work.

I believe others experience joy as a result of my work.

My spirit is energized by my work.

The work I do is connected to what I think is important in life.

I look forward to coming to work most days.

I see a connection between my work and the larger social good of my community.

I understand what gives my work personal meaning.

\section{Inner life $a=.822$}

I feel hopeful about life.

My spiritual values influence the choices I make.

I consider myself a spiritual person.

Prayer is an important part of my life.

I care about the spiritual health of my co-workers.

Work unit community $a=.871$

My immediate work unit cares about whether my spirit is energized by my work.

My immediate work unit makes it easy for me to use my gifts and talents at work.

My immediate work unit encourages employees to develop new skills and abilities.

My immediate work unit encourages the creation of community.

My immediate work unit takes into account the responsibilities I have to my family.

My immediate work unit is concerned about the poor in our community.

My immediate work unit cares about all its employees.

In my immediate work unit people are not encouraged to learn and grow (reversed).

Work unit and meaningful work $a=.914$

I feel positive about the values of my immediate work unit.

My immediate work unit has a conscience.

I feel connected with my immediate work unit's goals.

My immediate work unit is concerned.

I feel connected with the mission of my immediate work unit.

I feel positive about my future with my immediate work unit.

\section{References}

Alderfer, 1972 • C. P. Alderfer, Existence, relatedness, and growth, Free Press, New York (1972).

Ashforth \& Mael, 1989 - B. E. Ashforth and F. Mael, Social identity theory and the organization, Academy of Management Review 14 (1989), pp. 20-39.

Ashmos \& Duchon, 2000 - D. Ashmos and D. Duchon, Spirituality at work: A conceptualization and measure, Journal of Management Inquiry 9 (2000) (2), pp. 134-145.

Behrens, 1997 - J. T. Behrens, Principles and procedures of exploratory data analysis, Psychological Methods 2 (1997) (2), pp. 131-160.

Bellah et al., 1985 - R. R. Bellah, W. S. Madsden, A. Swinder, and S. Tipton, Habits of the heart, Harper and Row, New York (1985).

Bennis, 1999 • W. Bennis, Old dogs, new tricks, Executive Excellence Publishing, Provo, UT (1999).

Beyer, 1999 - J. M. Beyer, Culture, meaning and belonging at work. Paper presented at the 1999 Chicago Academy of Management Meeting.

Bolman \& Deal, 1995 • L. G. Bolman and T. E. Deal, Leading with soul, Jossey-Bass, San Francisco (1995).

Bolman \& Deal, 2003 • L. G. Bolman and T. E. Deal, Reframing organizations, Jossey-Bass, San Francisco (2003). 
Brief, 2001 - A. P. Brief, Organizational behavior and the study of affect: Keep your eyes on the organization, Organizational Behavior and Human Decision Processes 26 (2001) (1), pp. 131-139.

Brief \& Weiss, 2002 - A. P. Brief and H. M. Weiss, Affect in the workplace, Annual Review of Psychology 53 (2002), pp. 279-307.

Burke \& Litwin, 1992 - W. W. Burke and G. H. Litwin, A causal model of organizational performance and change, Journal of Management 18 (1992), pp. 523-545.

Cameron et al., 2003 • K. S. Cameron, J. E. Dutton, and R. E. Quinn, Positive organizational scholarship, Berrett-Koehler Publishers, Inc., San Francisco (2003).

Carlisle \& Manning, 1994 - Y. Carlisle and D. Manning, The concept of ideology and work motivation, Organization Studies 15 (1994) (5), pp. 683-704.

Chatman, 1991 - J. A. Chatman, Matching people and organization: Selection and socialization in public accounting firms, Administrative Science Quarterly 36 (1991), pp. 459-484.

Conger, $1994 \cdot$ J. A. Conger, Spirit at work, Jossey-Bass, San Francisco (1994).

Day \& Bedian, 1991 - D. V. Day and A. G. Bedian, Predicting job performance across organizations: The interaction of work orientation and psychological climate, Journal of Management 17 (1991) (3), pp. 589-600.

Dehler \& Welsh, 2003 - G. E. Dehler and M. A. Welsh In: R. A. Giacalone and C. L. Jurkiewics, Editors, The handbook of workplace spirituality and organizational performance, M. E. Sharpe, New York (2003), pp. 2108-2122.

Delbecq, 2000 - A. E. Delbecq, Spirituality for business leadership: Reporting on a pilot course for MBAs and CEOs, Journal of Management Inquiry 9 (2000) (2), pp. 117-128.

Dutton, 2003 • J. E. Dutton, Energize your workplace, Jossey-Bass, San Francisco (2003).

Dutton \& Dukerich, 1991 - J. E. Dutton and J. M. Dukerich, Keeping an eye on the mirror: The role of image and identity in organizational adaptation, Academy of Management Journal 34 (1991), pp. 517-554.

Dutton et al., 1994 - J. E. Dutton, J. M. Dukerich and C. V. Harquail, Organizational images and member identification, Administrative Science Quarterly 39 (1994), pp. 239-263.

Dutton \& Heaphy, 2003 • J. E. Dutton and E. D. Heaphy, The power of high-quality connections. In: K. S. Cameron, J. E. Dutton and R. E. Quinn, Editors, Positive organizational scholarship, Berrett-Koehler Publishers, Inc., San Francisco (2003), pp. 263-278.

Ellemers et al., 2004 • N. Ellemers, D. De Gilder and S. Haslam, Motivating individuals and groups at work: A social identity perspective on leadership and group performance, Academy of Management Review 29 (2004), pp. 459-478.

Elm, 2003 - D. R. Elm, Honesty, spirituality, and performance at work. In: R. A. Giacalone and C. L. Jurkiewics, Editors, The handbook of workplace spirituality and organizational performance, M. E. Sharpe, New York (2003), pp. 277-288.

Etzioni, 1995 - A. Etzioni, The socio-economics of work. In: F. C. Gamst, Editor, Meanings of work: Considerations for the twenty-first century, State University of New York Press, Albany (1995), pp. 251-260.

Ferris et al., 1998 • G. R. Ferris, M. M. Arthur, H. M. Berkson, D. M. Kaplan, G. Harrell-Cook, and D. D. Frink, Toward a social context theory of human resource management-organizational effectiveness relationship, Human Resource Management Review 8 (1998), pp. 235-264.

Fishbein \& Ajzen, 1975 - M. Fishbein and I. Ajzen, Belief, attitude, intention, and behavior: An introduction to theory and research, Addison-Wesley, Reading, MA (1975).

Fox, 1994 - M. Fox, The reinvention of work, Harper, San Francisco (1994).

Fry, 2003 - L. W. Fry, Toward a theory of spiritual leadership, The Leadership Quarterly 14 (2003), pp. 693-727.

Fry et al., 2005 - L. W. Fry, S. Vitucci, and M. Cedillo, Spiritual leadership and army transformation: Theory, measurement, and establishing a baseline, The Leadership Quarterly's Special Issue on Spiritual Leadership 16 (2005), pp. 835-863.

Gallup, 1998 • F. Gallup Jr., The Gallup poll: Public opinion 1997, Scholarly Resources Inc., Wilmington, Del (1998).

Garcia-Zamor, 2003 - J.-C. Garcia-Zamor, Workplace spirituality and organizational performance, Public Administration Review 63 (2003) (3), pp. 355-363.

Giacalone \& Jurkiewicz, 2003 - R. A. Giacalone and C. L. Jurkiewicz, Toward a science of workplace spirituality. In: R. A. Giacalone and C. L. Jurkiewics, Editors, The handbook of workplace spirituality and organizational performance, M. E. Sharpe, New York (2003), pp. 3-28.

Guest, 1957 • R. R. Guest, Job enlargement-a revolution in job design, Personnel Administration (1957), pp. 9-16.

Hackman \& Lawler, $1971 \bullet$ J. R. Hackman and E. Lawler, Employee reactions to job characteristics, Journal of Applied Psychology (1971), pp. 159-170.

Hackman \& Oldham, 1976 • J. R. Hackman and G. R. Oldham, Motivation through the design of work: Test of a theory, Organizational Behavior and Human Performance 16 (1976), pp. 250-279. 
Hackman \& Oldham, 1980 • J. R. Hackman and G. Oldham, Work design, Addison-Wesley, Reading, MA (1980).

Herzberg, 1974 • F. Herzberg, The wise old Turk, Harvard Business Review (1974, September-October), pp. 70-80.

James \& James, 1989 - L. A. James and L. R. James, Integrating work environment perceptions: Explorations into the measurement of meaning, Journal of Applied Psychology 74 (1989), pp. 739-751.

James \& McIntyre, 1996 • L. R. James and M. D. McIntyre, Perceptions of organizational climate. In: K. R. Murphy, Editor, Individual differences and behavior in organizations, Jossey-Bass, San Francisco (1996), pp. 416-450.

Kets de Vries, 1998 - M. F. R. Kets de Vries, Charisma in action: The transformational abilities of Virgins Richard Branson and ABB's Percy Barnevik, Organizational Dynamics 3 (1998), pp. 7-21.

Kolodinsky et al., 2003 - R. W. Kolodinsky, M. G. Bowen and G. R. Ferris, Embracing workplace spirituality and managing organizational politics: Servant leadership and political skill for volatile times. In: R. A. Giacalone and C. L. Jurkiewics, Editors, The handbook of workplace spirituality and organizational performance, M. E. Sharpe, New York (2003), pp. 164-180.

Kouzes \& Pozner, 1987 • J. M. Kouzes and B. Z. Pozner, The leadership factor, Free Press, New York (1987).

Kramer, 1991 - R. Kramer, Intergroup relations and organizational dilemmas: The role of categorization processes. In: L. L. Cummings and Barry M. Staw, Editors, Research in organizational behavior, vol. 13, JAI Press, Greenwich, CT (1991), pp. 191-228.

Lawler, 1973 • E. E. Lawler, Motivation in work organizations, Brooks-Cole, Monterey, CA (1973).

Learner, 1996 • M. Learner, The politics of meaning, Addison-Wesley, Reading, MA (1996).

Leonard et al., 1995 - N. H. Leonard, L. Beauvais and R. W. School, A self concept-based model of work motivation, Academy of Management Best Paper Proceedings (1995), pp. 322-327.

Levy, 2000 - R. B. Levy, My experience as participant in the course on spirituality for executive leadership, Journal of Management Inquiry 9 (2000), pp. 129-131.

Malone \& Fry, 2003 - P. Malone and L. W. Fry, Transforming schools through spiritual leadership: A field experiment. Paper presented at the National Academy of Management Meeting, Seattle, WA, 2003.

Manning \& Robinson, 1985 - D. J. Manning and T. J. Robinson, The place of ideology in political life, Croom Helm, London (1985).

Maslach \& Leiter, 1997 • C. Maslach and M. P. Leiter, The truth about burnout, Jossey-Bass, San Francisco (1997).

Maslow, $1954 \cdot$ A. Maslow, Motivation and personality, Harper and Row, New York (1954).

McClelland, $1961 \bullet$ D. C. McClelland, The achieving society, D. Van Nostrand: Harcourt, Brace, New York (1961).

McMillan \& Chavis, 1986 - D. W. McMillan and D. M. Chavis, Sense of community: A definition and theory, Journal of Community Psychology 14 (1986), pp. 6-23.

Mirvis, 1997 • P. H. Mirvis, “Soul work” in organizations, Organization Science 8 (1997) (2), pp. $193-206$.

Mitchell et al., 2001 • T. Mitchell, B. C. Holtom, T. W. Lee, C. J. Sablynski and M. Erez, Why people stay: Using job embeddedness to predict voluntary turnover, Academy of Management Journal 44 (2001) (6), pp. 1102-1121.

Mitroff \& Denton, 1999 - I. I. Mitroff and E. Denton, A study of spirituality in the workplace, Sloan Management Review 40 (1999) (4), pp. 83-93.

Mitroff et al., 1994 - I. I. Mitroff, R. O. Mason and C. M. Pearson, Radical surgery: What will tomorrow's organizations look like?, Academy of Management Executive 8 (1994), pp. 11-21.

Morris \& Feldman, 1996 - J. A. Morris and D. C. Feldman, The dimensions, antecedents, and consequences of emotional labor, Academy of Management Review 21 (1996) (4), pp. 986-1010.

O'Reilly et al., 1989 • C. A. O'Reilly, D. F. Caldwell and W. P. Barnett, Workgroup demography, social integration and turnover, Administrative Science Quarterly 34 (1989), pp. 21-37.

O'Reilly et al., 1991 • C. O’Reilly, J. Chatman and D. Caldwell, People and organizational culture: A profile comparison approach to person-organization fit, Academy of Management Journal 34 (1991), pp. 487-516.

Ostroff, 1992 - C. Ostroff, The relationship between satisfaction, attitudes, and performance: An organizational level analysis, Journal of Applied Psychology (1992), pp. 963-974.

Ouimet, Robert - Robert Ouimet, The universal and long-term application of Our Project in all businesses and organizations; http://www.our-project.org

Pfeffer, 2003 - J. Pfeffer, Business and the spirit: Management practices that sustain values. In: R. A. Giacalone and C. L. Jurkiewics, Editors, The handbook of workplace spirituality and organizational performance, M. E. Sharpe, New York (2003), pp. 29-45.

Pfeffer \& Baron, 1988 - J. Pfeffer and J. N. Baron, Taking the workers back out: Recent trends in the structuring of employment. In: B. M. Staw and L. L. Cummings, Editors, Research in organizational behavior, vol. 10, JAI Press, Greenwich, CT (1988), pp. 257-303. 
Pine \& Gilmore, 1998 - B. J. Pine and J. H. Gilmore, Welcome to the experience economy, Harvard Business Review (1998), pp. 97-105 July-August.

Pratt \& Ashforth, 2003 - M. G. Pratt and B. E. Ashforth, Fostering meaningfulness in working and at work. In: K. S. Cameron, J. E. Dutton and R. E. Quinn, Editors, Positive organizational scholarship, Berrett-Koehler, San Francisco (2003), pp. 309-327.

Roberson, 1990 - L. Roberson, Functions of work meanings in organizations: Work meanings and work motivation. In: A. P. Brief and W. R. Nord, Editors, Meanings of occupational work: A collection of essays, Lexington Books, Lexington, MA (1990), pp. 107-134.

Rogg et al., 2001 - K. L. Rogg, D. B. Schmidt, C. Shull, and N. Schmitt, Human resource practices, organizational climate, and customer satisfaction, Journal of Management 27 (2001), pp. 431-449.

Ryan et al., 1996 - A. M. Ryan, M. J. Schmit, and R. Johnson, Employee attitudes and effectiveness: Examining relations at an organizational level, Personnel Psychology 48 (1996), pp. 521-536.

Salancik \& Pfeffer, 1978 - G. R. Salancik and J. Pfeffer, A social information processing approach to job attitudes and task design, Administrative Science Quarterly 23 (1978), pp. 224-253.

Schmit \& Allschied, 1995 - M. J. Schmit and S. P. Allschied, Employee attitudes and effectiveness: Examining relations at an organizational level, Personnel Psychology 48 (1995), pp. 853-863.

Shamir, 1991 - B. Shamir, Meaning, self and motivation in organizations, Organization Studies 12 (1991) (3), pp. 405-424.

Strack et al., 2002 • G. Strack, M. D. Fottler, M. J. Wheatley, and P. Sodomka, Leadership and spirituality, Frontiers of Health Services 18 (2002), pp. 3-19.

Szilagyi \& Wallace, 1987 - A. D. Szilagyi and M. J. Wallace, Organizational behavior and performance, Scott, Forsman and Company, Glenview, IL (1987).

Tajfel \& Turner, $1985 \bullet$ H. Tajfel and J. C. Turner, The social identity theory of intergroup behavior. In: S. Worchel and W. G. Austin, Editors, Psychology of intergroup relations, Nelson-Hall, Chicago (1985), pp. 7-24.

Terkel, $1985 \cdot$ S. Terkel, Working, Ballantine, New York (1985).

Tichy \& Devanna, 1986 • N. M. Tichy and M. A. Devanna, The transformational leader, Wiley, New York (1986).

Tukey, $1977 \bullet$ J. W. Tukey, Exploratory data analysis, Addison-Wesley, Reading, MA (1977).

Vaill, $1998 \cdot$ P. Vaill, Spirited leading and learning, Jossey-Bass, San Francisco (1998).

Vaill, 2000 - P. Vaill, Introduction to spirituality for business leadership, Journal of Management Inquiry 9 (2000) (2), pp. 115-116.

Vroom, 1964 • V. H. Vroom, Work and motivation, Wiley, New York (1964).

Weisbord, 1991 M. R. Weisbord, Productive workplaces: organizing and managing for dignity, meaning, and community, Jossey-Bass, San Francisco (1991).

White, 2003 - R. D. White, Drawing the line: Religion and spirituality in the workplace. In: R. A. Giacalone and C. L. Jurkiewics, Editors, The handbook of workplace spirituality and organizational performance, M. E. Sharpe, New York (2003), pp. 244-256.

Wrzesniewski, 2003 - A. Wrzesniewski, Finding positive meaning in work. In: K. S. Cameron, J. E. Dutton and R. E. Quinn, Editors, Positive organizational scholarship, Berrett-Koehler, San Francisco (2003), pp. 296-308.

Wrzesniewski \& Dutton, 2001 - A. Wrzesniewski and J. Dutton, Crafting a job: Revisioning employees as active crafters of their work, Academy of Management Review 26 (2001) (2), pp. 179-201. 